Jurnal Riset Biologi dan Aplikasinya, Volume 2, Nomor 1, Maret 2020

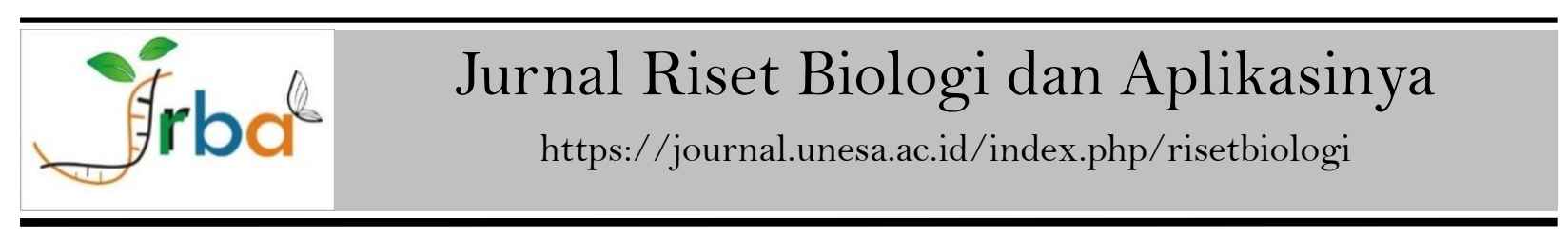

\title{
Prevalensi Kejadian Aglutinasi Spermatozoa Rattus norvegicus Strain Wistar Albino yang Diberi Paparan Antibiotik Kanamycin
}

\author{
Spermatozoid Agglutination Prevalence in Rattus norvegicus by Kanamycin Administration
}

Muhammad Saka Abeiasa*

Jurusan Keperawatan, Sekolah Tinggi Kesehatan Piala Sakti Pariaman

\begin{abstract}
Article History
$\overline{\text { Received : } 16 \text { Desember 2019 }}$

Approved : 8 Maret 2020

Published : 31 Maret 2020

Kata Kunci: aglutinasi, spermatozoa, antibiotik, kanamiycn

Keywords: agglutination, spermatozoa, antibiotik, kanamycin

Abstrak

Kelompok antibiotik dari golongan aminoglikosida seperti kanamycin dan gentamycin menyebabkan kesalahan penerjemahan dan efek inhibisi pada proses translokasi t-RNA dan m-RNA bakteri. Telah dilaporkan bahwa toksisitas kanamycin dapat meningkat seiring dengan peningkatan dosis yang diterima. Hal ini dapat berakibat penurunan jumlah dan kecacatan spermatozoa. Penelitian ini bertujuan untuk menguji pengaruh antibiotik kanamycin terhadap prevalensi kejadian aglutinasi spermatozoa. Jumlah aglutinasi spermatozoa dihitung menggunakan agglutination grade WHO. Penelitian ini merupakan penelitian eksperimental dengan model post-test-only control group design dengan variabel independen yaitu kanamycin dosis bertingkat dan variabel dependen yaitu jumlah aglutinasi spermatozoa. Data dianalisis menggunakan ANAVA dan dilanjutkan dengan uji lanjut Bonferroni. Hasil penelitian menunjukkan bahwa pemberian kanamycin dosis bertingkat berpengaruh terhadap prevalensi kejadian aglutinasi spermatozoa. Peningkatan jumlah aglutinasi seiring dengan peningkatan dosis yang diterima.
\end{abstract}

\begin{abstract}
Aminoglycocide-group-antibiotics such kanamycin and gentamycin caused mistranslation and inhibition effect for $t-R N A$ and $m-R N A$ translocation of bacteria. Kanamycin toxicity can increase along with increasing in dose received. This can cause the disability and decreasing amount of spermatozoa. This study aimed to examine the effect of kanamycin for spermatozoid agglutination prevalence. The amount of spermatozoid agglutination was counted by using agglutination grade WHO. This study was an experimental research with post-test-only control group design. The data was analyzed using ANAVA and followed by post-hoc Bonferroni test. The result showed that kanamycin multilevel dosing taken effect for spermatozoid agglutination prevalence. Increasing the amount of agglutination along with the increase in the dose received.
\end{abstract}

How to cite: Abeiasa, M. S. (2020). Prevalensi Kejadian Aglutinasi Spermatozoa Rattus norvegicus Strain Wistar Albino yang Diberi Paparan Antibiotik Kanamycin. Jurnal Riset Biologi dan Aplikasinya, 2(1), 1-5.

\footnotetext{
\& *orresponding Author:

e-ISSN 2655-9927

Jln. Diponegoro No 05 Kp. Pondok Pariaman 25512 Sumatera Barat,

Indonesia Sumatera Barat, Indonesia

E-mail: 13abeiasa@gmail.com
} 


\section{PENDAHULUAN}

Pembuktian tentang efek samping penggunaan antibiotik terhadap spermatogenesis telah banyak dilakukan pada hewan coba. Pada manusia masalah infertilitas merupakan kasus dengan banyak faktor etiologi sehingga dalam penetapan diagnosis perlu analisis yang tepat. Penggunaan jangka panjang antibiotik pada manusia diketahui memberi efek samping yang merugikan, hal ini dikarenakan oleh terjadinya peningkatan radikal bebas akibat metabolisme antibiotik tersebut. Antibiotik dari golongan aminoglikosida, macrolida, tetraxyclin, dan obat golongan sulfat diketahui memiliki efek samping terhadap kejadian infertilitas pria.

Kelompok antibiotik dari golongan aminoglikosida, misalnya kanamycin dan gentamycin, menyebabkan kesalahan penerjemahan dan efek inhibisi pada proses translokasi t-RNA dan m-RNA pada bakteri. Kanamycin juga mengintervensi perkembangan ribosom sehingga mengakibatkan ribosom mensintesis polipeptida yang tidak lengkap, hal ini diketahui dapat bekerja baik terhadap bakteri, namun memberikan efek samping berupa peningkatan translokasi pada membran sel yang dapat berakibat pada stres seluler (Liu \& Imlay, 2013). Inti niamin pada antibiotik golongan aminoglikosida memediasi sequence spesific binding pada situs-A ribosom (Salian et al., 2012). Kanamycin dipergunakan secara injeksi intramuskular pada area gluteal dengan dosis yang disesuaikan berdasarkan berat badan resipien. Pada kasus infeksi gonorrhea, kanamycin umum dipergunakan sebagai alternatif yang dipilih ketika terjadi resistensi terhadap antibiotik lain (WHO, 2016).

Toksisitas kanamycin dapat meningkat seiring dengan peningkatan dosis yang digunakan (Zhao et al., 2014) dan diketahui dapat meningkatkan reactive oxygen species (ROS) (Ye et al., 2018). Beberapa laporan tentang peningkatan kadar ROS yang berujung pada kematian sel akibat pengunaan antibiotik golongan aminoglikosida (kanamycin dan gentamycin) masih diperdebatkan (Ye et al., 2018). Beberapa agen antimikrobial tertentu menekan proses infeksi tanpa menginduksi ROS, namun beberapa antimicrobial yang lain, misalnya ofloxacin, bekerja di bawah pengaruh kadar oksigen tubuh terutama keadaan anoksia dan secara luas menekan bakteri melalui jalur ROS bebas (Keren et al., 2013). Aktivitas antibiotik dapat mengakibatkan dampak primer pada sel. Kerusakan pada sel ini dapat ditanggulangi oleh antioksidan dan ion besi. Aktivitas antibiotik lebih lanjut mengakibatkan akumulasi radikal bebas yang menyebabkan dampak sekunder yang berakhir pada kematian sel (Zhao et al., 2014).

Radikal bebas berperan aktif dalam memicu terjadinya penurunan populasi sel didalam tubuh. Kematian sel melalui jalur apoptosis dan nekrosis merupakan dampak terburuk. Hal ini juga dikaitkan sebagai faktor utama dalam kejadian oligozoospermia dan aglutinasi spermatozoa (Agarwal et al., 2008). Peningkatan ROS sebagai radikal bebas di dalam tubulus seminiferus mengakibatkan sel-sel germinal mengalami stres oksidatif yang dapat mengakibatkan kerusakan DNA. Perubahan pada gen yang dibawa spermatozoa dapat berakibat pada kesalahan pengkodean yang berujung pada penurunan populasi dan kecacatan spermatozoa.

Pada proses spermiogenesis dapat menimbulkan dampak tersendiri berupa perlekatan spermatozoa yang dikenal dengan aglutinasi sel sperma (Adewoyin et al., 2017). Peningkatan ROS pada sel spermatogenik juga diketahui dapat memicu agregasi leukosit yang selanjutnya mengintervensi fungsi spermatozoa dengan mengaktivasi jalur peroksidasi lipid membrane. Akibatnya kapasitasi akrosomal akan terjadi di dalam tubulus seminiferus. Namun, secara garis besar hubungan langsung Reactive Oxigen Species (ROS) terhadap kejadian aglutinasi spermatozoa masih sangat sedikit dan perlu dilakukan uji lanjut (American Urological Association, 2010). Penelitian ini bertujuan untuk menguji pengaruh antibiotik kanamycin terhadap prevalensi kejadian aglutinasi spermatozoa.

\section{BAHAN DAN METODE}

Penelitian ini merupakan penelitian eksperimen dengan desain penelitian post-test only control group design. Populasi penelitian adalah tikus jantan Wistar yang berumur 2-3 bulan, dengan berat badan kira-kira 300-350 g dengan jumlah sampel sebanyak 24 ekor. Perlakuan hewan coba dan pemeriksaan aglutinasi spematozoa dilakukan di Laboratorium Anatomi Fisiologi STIKES Piala Sakti Pariaman. Variabel independen adalah kanamycin dosis bertingkat dan variabel dependen adalah aglutinasi spermatozoa.

Sampel dibagi ke dalam empat kelompok yang berisi enam ekor tikus: 1 kelompok kontrol dan 3 kelompok eksperimen yang masing-masing diberi perlakuan kanamycin sulfat dengan dosis 10, 15, dan $20 \mathrm{mg} / \mathrm{bb} /$ hari (Susetijawati, 1996). Ruang uji dikontrol dengan siklus terang gelap. Pada akhir 
masa penelitian tikus dikorbankan untuk diambil cauda epididimisnya, epididimis yang telah diambil diletakkan ke dalam botol vial $10 \mathrm{ml}$ berisi garam fisiologis $(\mathrm{NaCl} \quad 0,9 \%)$ sebanyak $5 \mathrm{ml}$. Cauda epididimis didiamkan selama 15 menit agar spermatozoa keluar selanjutnya cairan yang telah berisi spermatozoa diambil 0,5 $\mathrm{ml}$ dan ditambah dengan larutan Gorge sebanyak o,5 ml dan diaduk agar homogen. Sebanyak $10 \mu \mathrm{l}$ cairan diambil menggunakan pipet tetes dan diletakkan pada hemositometer Improved Neubauer kemudian dihitung jumlah aglutinasi per lapang pandang dengan menggunakan derajat aglutinasi yang ditetapkan oleh WHO (2016). Data yang diperoleh dianalisis menggunakan uji statistik parametrik One Way Anova dan dilanjutkan dengan uji Multiple Comparisons (post hoc test) Bonferroni.

\section{HASIL DAN PEMBAHASAN}

Pengamatan terhadap kondisi spermatozoa yang diisolasi dari semua sampel menunjukkan kejadian aglutinasi spermatozoa pada kelompok perlakuan (Gambar 1). Aglutinasi merupakan kelainan umum yang terjadi karena proses reaksi inflamasi yang terjadi di tubulus seminiferus (Agarwal et al., 2008). Perlekatan spermatozoa dapat diakibatkan kesalahan informasi yang terjadi pada proses spermatogenesis maupun spermiogenesis (Berger et al., 2019). Perubahan morfologis pada spermatozoa tidak hanya karena kerusakan struktural membran, namun juga diikuti oleh kerusakan DNA dan subunit ribosom yang mengakibatkan kesalahan translasi (Hallaj Salahipour et al., 2019). Peningkatan kerusakan DNA memiliki korelasi yang kuat terhadap kerusakan struktur dan jumlah kejadian apoptosis pada spermatozoa (Khodair \& Omran, 2013).

Berdasarkan hasil analisis data jumlah kejadian aglutinasi spermatozoa diketahui bahwa terdapat perbedaan yang signifikan antara semua kelompok eksperimen dan antara kelompok eksperimen dengan kontrol $\left(\mathrm{P}_{\text {value }} \mathrm{O}, \mathrm{OO}\right)$ (Tabel 1). Kanamycin diketahui memiliki efek merusak pada sebagian besar spermatozoa mamalia (Hasan et al., 2001). Kerusakan yang terjadi pada spermatozoa dimungkinkan adanya mutasi pada DNA sel dan mitokondria yang terjadi akibat adanya induksi radikal bebas dan kerusakan pada membran sel (Gao et al., 2017).

ROS merupakan hasil sampingan dari proses kerja aminoglikosida di dalam tubuh. ROS potensial mengurangi kemampuan sel mengatur homeostasis yang berujung pada ketidakseimbangan secara fisiologis (Acharya et al., 2012). Antibiotik kelompok aminoglikosida juga menginduksi peningkatan radikal bebas pada kelompok yang diberikan antibiotik (Sha \& Schacht, 1999). Di dalam tubuh radikal bebas dapat menyebabkan perubahan struktural membran sel sehingga permeabilitas membran meningkat. Hal ini dapat mengakibatkan sel lisis sehingga berujung pada kerusakan sel dalam skala yang besar (Ye et al., 2018).
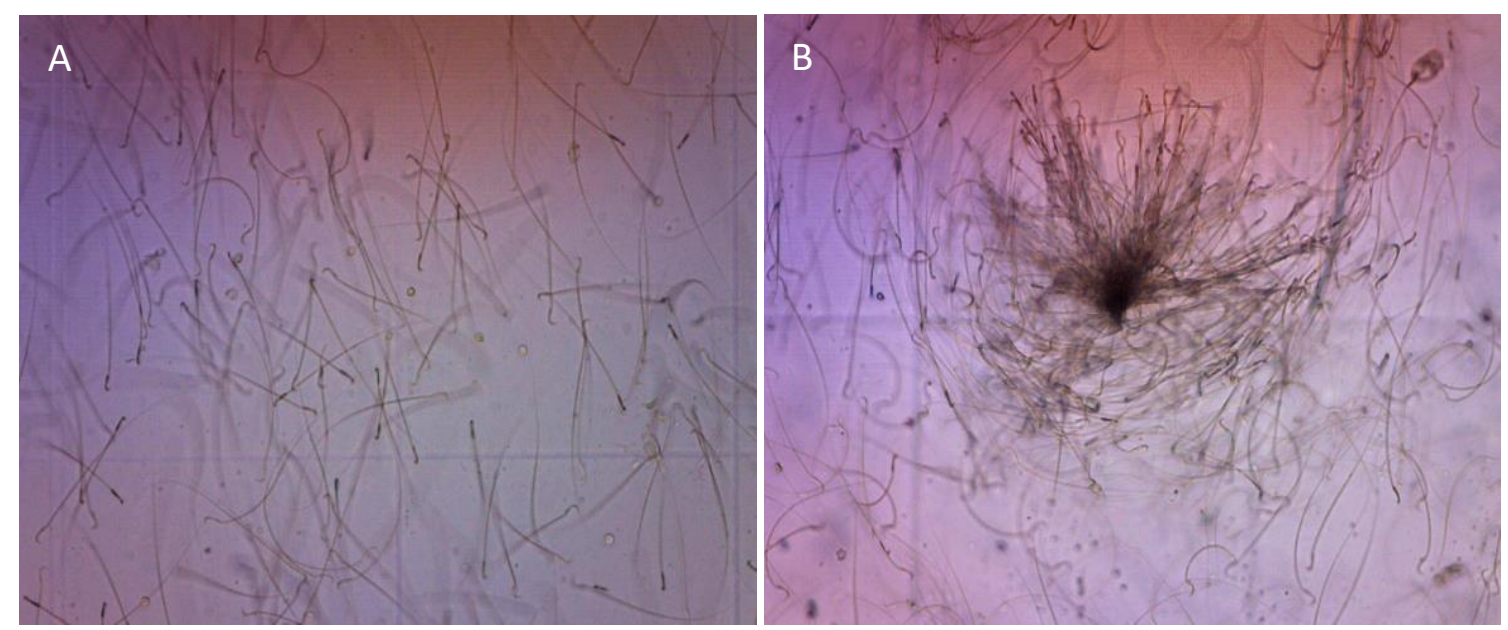

Gambar 1. Perbandingan aglutinasi spermatozoa hewan coba (A) kondisi spermatozoa kelompok kontrol; (B) aglutinasi spermatozoa yang terjadi pada kelompok perlakuan 
Tabel 1. Rata-rata jumlah aglutinasi spermatozoa hewan coba yang diberi kanamycin dosis bertingkat_(n=24)

\begin{tabular}{c|c|c}
\hline Kelompok & Rata-rata \pm SD & P \\
\hline Kontrol & $6,50 \pm 0,547^{\mathrm{a}}$ & \\
P1 & $17,00 \pm 3,687^{\mathrm{b}}$ & 0,000 \\
P2 & $29,33 \pm 4,273^{\mathrm{c}}$ & \\
P3 & $38,17 \pm 1,834^{\mathrm{d}}$ & \\
\hline
\end{tabular}

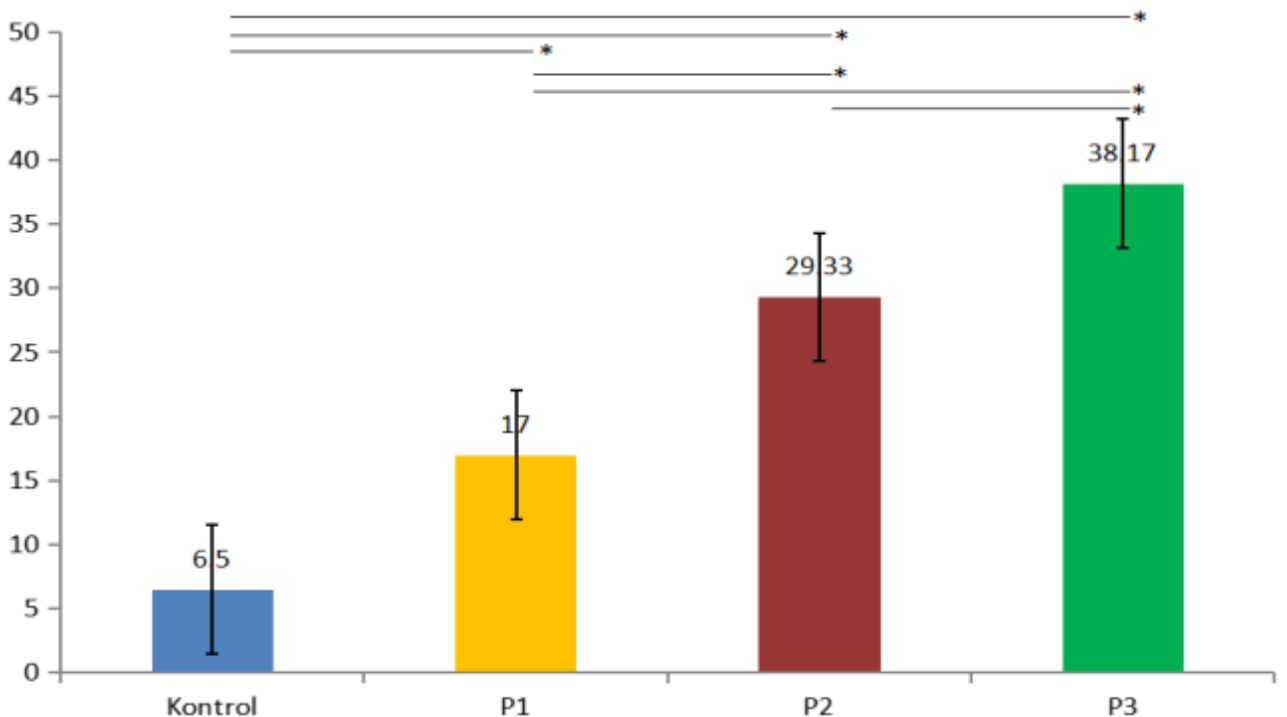

Gambar 2. Jumlah aglutinasi spermatozoa antarkelompok hewan coba yang diberi kanamycin dosis bertingkat ( $\mathrm{n}=24)$ Kontrol: tanpa injeksi Kanamycin; $\mathrm{P} 1$ : 10; $\mathrm{P} 2: 15 ; \mathrm{P} 3: 20$ (mg/bb/hari)

Berdasarkan hasil analisis data jumlah kejadian aglutinasi spermatozoa diketahui bahwa terdapat perbedaan yang signifikan antara semua kelompok eksperimen dan antara kelompok eksperimen dengan kontrol (Pvalue O,OO) (Tabel 1). Kanamycin diketahui memiliki efek merusak pada sebagian besar spermatozoa mamalia (Hasan et al., 2001). Kerusakan yang terjadi pada spermatozoa dimungkinkan adanya mutasi pada DNA sel dan mitokondria yang terjadi akibat adanya induksi radikal bebas dan kerusakan pada membran sel (Gao et al., 2017).

Penelitian ini juga membuktikan bahwa pemberian antibiotik kanamycin dengan dosis meningkat mengakibatkan aglutinasi spermatozoa yang lebih parah (Gambar 2). Hasil uji beda nyata menunjukkan bahwa semua kelompok, baik kelompok kontrol maupun kelompok eksperimen memiliki tingkat aglutinasi spermatozoa yang berbeda secara signifikan (Tabel 1). Seperti telah disampaikan di atas bahwa Kanamycin memiliki efek yang merusak (Hasan et al., 2001), karena di dalam tubuh metabolisme antibiotik menghasilkan ROS yang menyebabkan peningkatan permeabilitas membran (Sha \& Schacht, 1999; Acharya et al.,
2012) dan pada akhirnya memicu kematian sel (Gao et al, 2017).

Toksisitas kanamycin dan peningkatan ROS dapat meningkat seiring dengan peningkatan dosis yang diterima (Ye et al., 2018). Hal ini menjelaskan bagaimana dosis Kanamycin yang lebih tinggi pada penelitian ini menyebabkan aglutinasi yang lebih parah.

\section{SIMPULAN}

Berdasarkan hasil penelitian ini dapat disimpulkan bahwa Kanamycin secara nyata menyebabkan aglutinasi spermatozoa. Dosis Kanamycin secara nyata menyebabkan aglutinasi yang lebih parah.

\section{DAFTAR PUSTAKA}

Acharya, C., Thakar, H., Vajpeyee, S. K. (2012). A Study of Oxidative Stress in Gentamicin Induced Nephrotoxicity and Effect of Antioxidant Vitamin C in Wistar Rats. National Journal of Physiology, Pharmacy $\mathcal{E}^{\circ}$ Pharmacology, 3(1), 14-20. doi: 10.5455/njppp.2013.3.14-20.

Adewoyin, M., Ibrahim, M., Roszaman, R., Isa, M. L. M., Alewi, N. A. M, Rafa, A. A. A., \& Anuar, 
M. N. N. (2017). Male Infertility: The Effect of Natural Antioxidants and Phytocompounds on Seminal Oxidative Stress. Diseases, 5(9), 1-26. doi: 10.3390/diseases5010009.

Agarwal, A., Bragais, F. M., \& Sabanegh, E. (2008). Assessing Sperm Function. Urologic Clinics of North America, 35(2), 157-171. https://doi.org/10.1016/j.ucl.2008.01.012.

American Urological Association. (2010). The Optimal Evaluation of the Infertile Male: AUA Best Practice Statement. USA: AUA Publisher. Diakses dari https://www.researchgate.net/publication/24 2579257_The_Optimal_Evaluation_of_the_Inf ertile_Male_AUA_Best_Practice_Statement.

Berger, G. K., Smith-Harrison, L. I., \& Sandlow, J. I. (2019). Sperm agglutination: Prevalence and Contributory Factors. Andrologia, 51(5). doi:10.1111/and.13254

Gao, Z., Chen, Y., \& Guan, M. (2017). Mitochondrial DNA mutations associated with aminoglycoside induced ototoxicity. Journal of Otology, 12(1), 1-8. doi: 10.1016/j.joto.2017.02.001.

Hallaj Salahipour, M., Hasanzadeh, S., Malekinejad, H., Razi, M., \& Farrokhi-Ardebili, F. (2019). Deoxynivalenol reduces quality parameters and increases DNA damage in mice spermatozoa. Andrologia, 51(5). doi:10.1111/and.13238.

Hasan, S., Andrabi, S. M. H., Muneer, R., Anzar, M., \& Ahmad, N. (2001). Effects of A New Antibiotic Combination on Post-Thaw Motion Characteristics and Membrane Integrity of Buffalo and Sahiwal Bull Spermatozoa and on the Bacteriological Quality of Their Semen. Pakistan Vet Journal, 21(1), 6-11. Diakses dari http://agris.fao.org/agrissearch/search.do? recordID=PK2002000156.

Keren, I., Wu, Y., Inocencio, J., Mulcahy, L. R., \& Lewis, K. (2013). Killing by Bactericidal Antibiotics Does Not Depend on Reactive Oxygen Species. Science, 339(6124):1213-1216. doi: $10.1126 /$ science. 1232688.

Khodair, H. A., \& Omran, T. (2013). Evaluation of reactive oxygen species (ROS) and DNA integrity assessment in cases of idiopathic male infertility. Egyptian Journal of Dermatology and
Venereology, 33(2), 51-55. doi: $10.1126 /$ science. 1232688.

Liu, Y., \& Imlay, JA. (2013). Cell Death from Antibiotics without the Involvement of Reactive Oxygen Species. Science, 339 (6124), 1210-1213. doi: 10.1126/science.1232751.

Salian, S., Matt, T., Akbergenov, R., Harish, S., Meyer, M., Duscha, S., Shcherbakov, D., Bernet, B. B., Vasella, A., Westhof, E., \& Bottger, E. C. (2012). Structure-Activity Relationships among the Kanamycin Aminoglycosides: Role of Ring I Hydroxyl and Amino Groups. Antimicrobial Agents and Chemotherapy, 56 (12), 6104-6108. doi: 10.1128/AAC.01326-12.

Sha, S., \& Schacht, J. (1999). Stimulation of Free Radical Formation by Aminoglycoside Antibiotics. Hearing Research, 128(1-2), 112$118 . \quad$ https://doi.org/10.1016/So3785955(98)00200-7.

Susetijawati, E. (1996). Pengaruh Pemberian Kanamycin Sulfat Terhadap Perubahan Histopatologi Ginjal Tikus Putih (Rattus norvegicus). (Skripsi, Fakultas Kedokteran Hewan, Universitas Airlangga Surabaya). Diakses dari http://repository.unair.ac.id/id/eprint/57254.

World Health Organization. (2016). WHO Guidelines for The Treatment of Neisseria gonorrhoeae. Switzerland: WHO Publication

Ye, J., Su, Y., Lin, X., Lai, S., Li, W., Ali, F., Zheng, J., \& Peng, B. (2018). Alanine Enhances Aminoglycosides-Induced ROS Production as Revealed by Proteomic Analysis. Frontiers in Microbiology, 9 (29): $1-14, \quad$ doi: 10.3389/fmicb.2018.00029.

Zhao, H., Li, J., Han, B., Li, X., \& Chen, J. (2014). Improvement of Oxidative Stress Tolerance in Saccharomyces cerevisiae Through Global Transcription Machinery Engineering. Journal of Industrial Microbiology \& Biotechnology, 41(5), 869-878. doi:10.1007/s10295-014-1421-8. 